\title{
Factors Affecting Wastewater Treatment and Power Generation of Constructed Wetland Microbial Fuel Cell Systems
}

\author{
Qiong Wan ${ }^{1}$, Yingchun Ren ${ }^{1}$, Cen Wang ${ }^{2}$, Xinyan Zhang ${ }^{*}$, Kai Ju' ${ }^{1}$,e Li ${ }^{1}$, \\ Haokun Song ${ }^{1}$, Dongyang $\mathrm{Wei}^{3}$ \\ ${ }^{1}$ School of Architecture and Civil Engineering, Xi' an University of Science and Technology, \\ 58 Yanta Road, Xi'an 710054, China \\ ${ }^{2}$ Wuhan Water Supply and Drainage Engineering Design Institute Ltd, Hubei Wuhan 430034, China \\ ${ }^{3}$ Environment Development Centre, Ministry of Ecology and Environment, Beijing 100029, China
}

Received: 24 November 2020

Accepted: 10 April 2021

\begin{abstract}
Although there have been many studies on the process conditions of Constructed Wetlands (CW) and Microbial Fuel Cells (MFC), there are few studies on the Constructed Wetlands coupled with Microbial Fuel Cells. Currently, low power production is the main problem faced by Constructed Wetlands-Microbial Fuel Cell systems (CW-MFCs). This experiment intends to research the effects of HRT, influent COD and electrode spacing on wastewater treatment and power generation performance. In this experiment, CW-MFCs with two different electrode spacings $(18 \mathrm{~cm}$ for reactor $\mathrm{A}$ and $28 \mathrm{~cm}$ for reactor B) were set up under continuous flow conditions. The effects of HRT, influent COD and eletrode spacing on wastewater treatment and power generation performance were explored using a single-factor controlled variable method. Experiment results showed that the extension of HRT was beneficial for contaminants removal and the power generation of the CW-MFCs, but the excessive extension was ineffective for the electricity output. The optimal HRT of the CW-MFCs was $24 \mathrm{~h}$ when influent COD was $500 \mathrm{mg} \cdot \mathrm{l}^{-1}$. Improving influent COD within the appropriate range $\left(500 \sim 1000 \mathrm{mg} \cdot \mathrm{l}^{-1}\right)$ facilitated the power generation and contaminant removal performance of the CW-MFCs. The maximum output voltage and power density were obtained in reactor A when influent COD was $1000 \mathrm{mg} \cdot \mathrm{l}^{-1}$ and HRT was $24 \mathrm{~h}$, which were $548 \mathrm{mV}$ and $120 \mathrm{~mW} \cdot \mathrm{m}^{-3}$, respectively. Compared with reactor B, reactor with smaller electrode spacing achieved better electricity generation and contaminant degradation under the optimal condition. Its average output voltage could be improved by 5.1 46.1\% and the removal rates of COD and $\mathrm{NH}_{4}{ }^{+}-\mathrm{N}$ could also be improved by $0.2 \sim 4.9 \%$ and $-0.9 \sim 13.7 \%$, respectively. This phenomenon indicates that there was a significant positive correlation between the number of Gram-negative bacteria and
\end{abstract}

*e-mail: xyzhang2020@xust.edu.cn 
the electricity production performance of the CW-MFCs, which was due to the difference in electron transfer efficiency. This study can provide operation parameters for the CW-MFCs process.

Keywords: constructed wetland microbial fuel cell, electricity generation, HRT, COD, electrode spacing

\section{Introduction}

Constructed Wetland (CW) is a compound system composed of plants, fillers and microorganisms, which has the advantages of simple structure, low operating cost and green environmental protection. It is considered as an efficient and energy-saving sewage treatment technology [1]. Microbial Fuel Cell (MFC) is a bioreactor which is composed of cathode, anode, reactor, ion exchange membrane and external circuit. Using microorganism as catalyst, the bioreactor can directly convert chemical energy into electric energy, which can realize the production of renewable energy and wastewater treatment [2]. Constructed WetlandMicrobial Fuel Cell system (CW-MFCs) combines the advantages of both, which can not only improve the efficiency of sewage treatment, but also recover part of the electric energy. It is a new sewage treatment technology in recent years [3-5]. The power generation and sewage purification performance of CW-MFCs are closely related to operation mode, influent organic load, hydraulic retention time, electrode spacing, electrode material, reactor size and power-producing microorganisms [6-9]. Shewanella, Geobacter and Pseudomonas are common electron-producing bacteria with good electron transfer capabilities [10,11]. The genus Sulfuritalea has been shown to be a parthenogenic anaerobic sulphur-oxidizing bacterium, associated with organic matter degradation, and which can use nitrate as an electron acceptor and has denitrification capacity [12]. Thauera is a parthenogenic anaerobic bacterium with denitrification capacity and is widely used in all types of wastewater treatment plants [13]. Anaerofustis is an anaerobic bacterium, associated with the oxidative degradation of organic matter [14]. The presence of these genera ensures to a certain extent the effluent treatment and power production performance of CW-MFCs. Wang et al. [15] used carbon fiber mat and graphite as electrode materials for CW-MFCs, and found that they had higher COD removal rate and output voltage. Doherty L et al. [16] used a combination of stainless steel mesh and granular activated carbon as the cathode material for CW-MFCs and achieved a maximum power density of $55.05 \mathrm{~mW} \cdot \mathrm{m}^{-2}$ for the system. Using common electrode materials (such as carbon, graphite and stainless steel mesh) instead of traditional MFC precious metal cathodes can greatly reduce the cost of electrode materials, which is the focus of largescale CW-MFCs research $[16,17]$. Ge et al. $[18,19]$ found that the power density decreases with the increase of MFC reactor volume: when the reactor volume of $\mathrm{MFC}<50 \mathrm{ml}$, the maximum power density is more than $500 \mathrm{~W} \cdot \mathrm{m}^{-3}$; when the reactor volume $>2000$ $\mathrm{ml}$, the power density is less than $30 \mathrm{~W} \cdot \mathrm{m}^{-3}$. Ieropoulos et al. [20, 21] made a comparative study of different sizes of MFC under the condition of continuous flow, and found that small MFC has higher output voltage than medium and large ones, and the more series units, the higher the power density and output voltage. However, small MFC is only suitable for laboratory research, not suitable for large-scale production and practical applications. Therefore, in order to provide technical support for further research and practical application of CW-MFCs, this experiment takes largescale CW-MFCs as the research object, taking into account the effects of hydraulic retention time, influent matrix and electrode spacing. The optimization of these factors is of great practical and reference significance for the low cost and high efficiency operation of the reactor.

Hydraulic retention time (HRT) reflects the amount of "fuel" that can be obtained by the electrogenic bacteria and the reaction time between microorganisms and organic matter, which significantly impacts the power output of the CW-MFCs. Previous literature [2226] reported diverse power generation performances under different HRTs in MFCs. A laboratory experiment showed that the optimal HRT was $9 \mathrm{~d}$ and the maximum output voltage was $82.1 \mathrm{mV}$, with maximum COD and sulphide removal efficiencies of $98 \%$ and $98.98 \%$ respectively [26]. In a study of MFC treatment of animal carcass wastewater, the maximum power density $\left(\mathrm{P}_{\mathrm{m}}\right)$ of the system was $2.19 \mathrm{~W} \cdot \mathrm{m}^{-3}$ for a HRT of $72 \mathrm{~h}$, with $\mathrm{COD}$ and $\mathrm{NO}_{3}^{-}-\mathrm{N}$ removal efficiencies of $50.66 \%$ and $79.76 \%$ respectively [22]. However, the exploration of best HRT of the CW-MFCs has not received sufficient attention so far as most studies were based on a fixed HRT. For example, Wang et al. [15] explored the effect of the $\mathrm{C} / \mathrm{N}$ ratio of the influent on the denitrification performance of the CW-MFCs at HRT of $36 \mathrm{~h}$. Few studies investigated the optimal HRT of the CW-MFCs. The optimization of HRT is worthy of attention to ensure a better power output of the CW-MFCs .

The influent COD concentration affects the power generation more directly than HRT. Although many studies explored the effect of influent organic loading on CW-MFCs, the influent COD concentration was generally at a low level. For example, Tang et al. [27] reported that a $\mathrm{P}_{\mathrm{m}}$ of $7.99 \mathrm{~mW} \cdot \mathrm{m}^{-2}$ could be achieved when influent COD was $500 \mathrm{mg} \cdot \mathrm{l}^{-1}$, with $\mathrm{COD}$ and $\mathrm{NH}_{4}^{+}-\mathrm{N}$ removal efficiencies of $91.7 \%$ and $97.3 \%$ respectively. When influent COD was $652 \mathrm{mg} \cdot \mathrm{l}^{-1}$ [28], the average output voltage of the CW-MFCs constructed with graphite and gravel anode materials were about $123 \mathrm{mV}$ and $102 \mathrm{mV}$, respectively. In summary, the relevant experiments were conducted at a low influent 
COD concentration, and the CW-MFCs showed a lower power generation performance. The coupled system may output more electric energy when it is run with high-concentration COD wastewater (such as food and beverage wastewater). Therefore, it is valuable to explore the power generation performance of the CWMFCs under high organic load.

Moreover, electrode spacing also greatly influences the electricity generation and contaminant degradation of the CW-MFCs. Although the decrease of electrode spacing could reduce internal resistance of the CWMFCs [29], it could also reduce the difference of redox potential between both electrodes which would affect the favorable anaerobic environment of the electrogenic bacteria. In different electrode spacings (10, 12 and $15 \mathrm{~cm}$ ), the MFC was reported to obtain the maximum output voltage $(900 \mathrm{mV})$ and $\mathrm{COD}$ removal rate was $94 \%$ at an electrode spacing of $10 \mathrm{~cm} \mathrm{[30].} \mathrm{In} \mathrm{addition,}$ the reduced electrode spacing not only reduced the Ohmic internal resistance (from $406.79 \Omega$ to $72.61 \Omega$ ), but also significantly promoted the decolorization performance of CW-MFCs, the power density of the system was the highest $\left(160 \mathrm{~mW} \cdot \mathrm{m}^{-3}\right)$ as the distance between electrodes was $6.6 \mathrm{~cm}$ [31]. The MFC was embedded in the CW system and the electricity production performance of the CW-MFCs was different from MFC. Although several studies reported the effect of electrode spacing on the power generation of MFC, the optimization of electrode spacing of CWMFCs has not received sufficient attention, especially for the cathode with aeration. In order to provide more references for scaled and commercial production of the CW-MFCs, it is significant to explore the effect of electrode spacing on both wastewater purification and power generation in the CW-MFCs.

Although many scholars have done a lot of research on the factors affecting the power generation and sewage purification performance of CW-MFCs, there are some differences in the results under different experimental conditions. At present, there is still a lack of discussion on the optimization of operation parameters in the application of single-chamber biological cathode $\mathrm{CW}-\mathrm{MFCs}$ in sewage treatment. In this paper, a constructed wetland-microbial fuel cell coupling system was constructed under the condition of continuous flow to explored the effects of HRT (12, 24 and $48 \mathrm{~h}$ ), influent COD (500, 1000 and $2000 \mathrm{mg} \cdot \mathrm{l}^{-1}$ ) and electrode spacing (18 and $28 \mathrm{~cm}$ ) on wastewater treatment and power generation performance. The research will provide the optimal operation parameters for further actual operation of CW-MFCs.

\section{Materials and Methods}

\section{Construction, Inoculation, and Operation of the System}

Two identical integrated up-flow reactors with different electrode distances (A was $18 \mathrm{~cm}$ and B was $28 \mathrm{~cm})$ were constructed to simulate the CW-MFCs reactor as shown in Fig. 1. Two reactors were built of organic glass with length, width, and height of $40 \times$ $12 \times 60 \mathrm{~cm}$, respectively. The anode electrodes of both reactors were composed of granular activated carbon (equivalent diameter of $4 \sim 8 \mathrm{~mm}$ ) wrapped in stainless steel mesh. The size of the stainless-steel mesh frame was $13 \times 6 \times 16 \mathrm{~cm}$, the mesh size was $9 \times 9 \mathrm{~mm}$. And the cathode electrode was composed of a $13 \times 6 \mathrm{~cm}$ sheet of stainless-steel mesh. The distribution zone was $3 \mathrm{~cm}$ high and located at the bottom of the reactor. And the top of this zone was a uniform water distribution orifice plate. Zeolite filler (equivalent diameter 4 6 $\mathrm{mm}$, height $44 \mathrm{~cm}$ ) embedded the anode, while the cathode electrode was placed above the water gathering
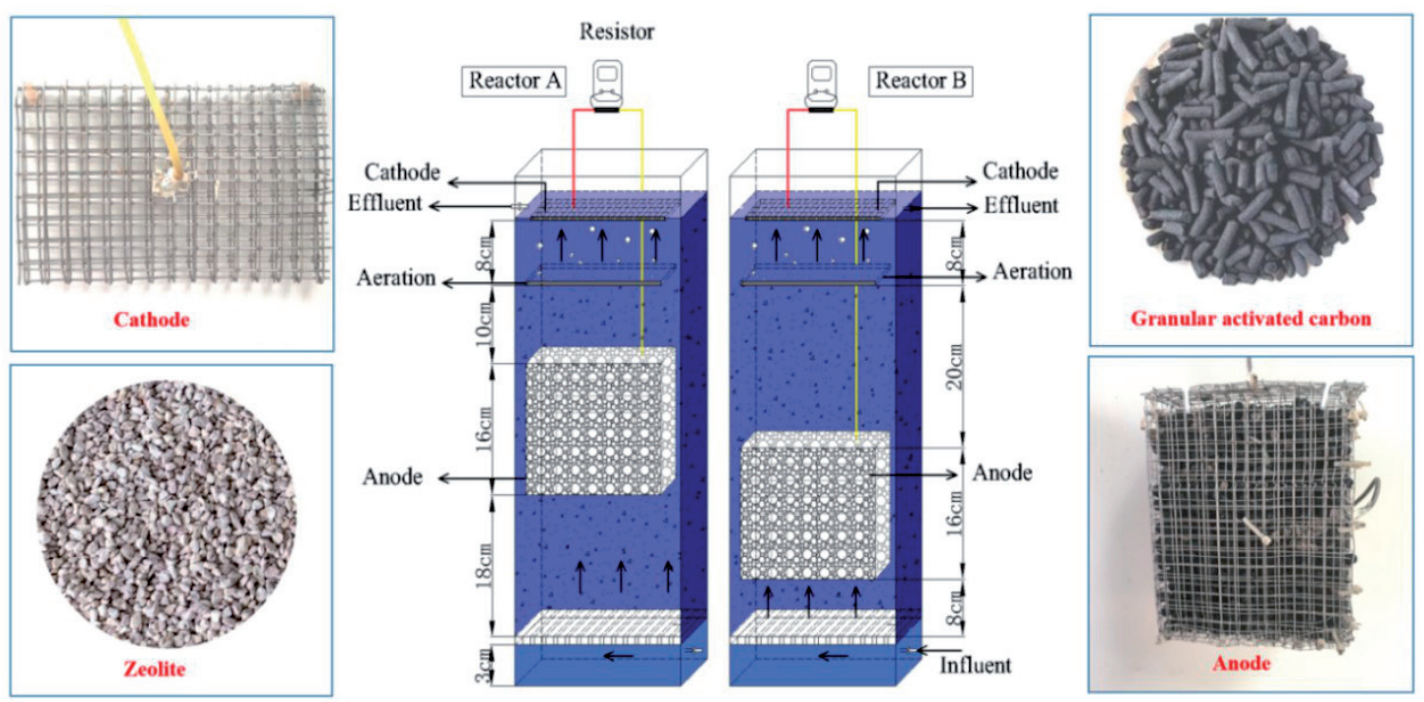

Fig. 1. Schematic diagram of the CW-MFCs. 
Table 1. Working conditions of all stages of the CW-MFCs.

\begin{tabular}{|c|c|c|c|c|c|c|c|}
\hline Stage & Start-up & $1-1$ & $1-2$ & $1-3$ & $2-1$ & $2-2$ & $2-3$ \\
\hline Time (d) & $1 \sim 20$ & $21 \sim 27$ & $28 \sim 39$ & $40 \sim 51$ & $52 \sim 63$ & $64 \sim 75$ & $76 \sim 82$ \\
\hline HRT (h) & 48 & 12 & 24 & 48 & \multicolumn{3}{|c|}{24} \\
\hline $\mathrm{O}_{2}\left(\mathrm{mg} \cdot \mathrm{l}^{-1}\right)$ & \multicolumn{5}{|c|}{4.13} & 3.24 & 2.06 \\
\hline Average $\mathrm{COD}_{\mathrm{inf}}\left(\mathrm{mg} \cdot \mathrm{l}^{-1}\right)$ & 504 & & 517 & & 512 & 1008 & 2013 \\
\hline Average $\mathrm{NH}_{4}^{+}-\mathrm{N}_{\mathrm{inf}}\left(\mathrm{mg} \cdot \mathrm{l}^{-1}\right)$ & 25.02 & & 24.73 & & 25.29 & 38.74 & 39.45 \\
\hline
\end{tabular}

area. The height of the water collection zone was $8 \mathrm{~cm}$. The outer circuit consisted of a copper wire and a $2000 \Omega$ external resistors. Because the low effect of plants on contaminant removal in constructed wetland, the reactors do not grow plants in this experiment.

The reactor was inoculated with a mixture of bacteria and synthetic wastewater (main components was same as stage 1) during the start-up stage. The mixed strains were Shewanella and anaerobic sludge from a sewage treatment plant of a university in $\mathrm{Xi}$ 'an. The hydraulic conditions and main components of the influent during each operating stage of reactors are shown in Table 1. The influent water nutrient contents were $\mathrm{CH}_{3} \mathrm{COONa}$, $\mathrm{NH}_{4} \mathrm{Cl}, \quad \mathrm{KH}_{2} \mathrm{PO}_{4} \quad\left(\mathrm{mg} \cdot \mathrm{l}^{-1}\right)$, and trace elements $\left(0.250 \mathrm{~mL} \cdot \mathrm{l}^{-1}\right)$. The proportions of trace element solution was as follows: $\mathrm{ZnSO}_{4} .7 \mathrm{H}_{2} \mathrm{O} 0.110 \mathrm{mg} \cdot l^{-1}, \mathrm{NaMO}_{4}$ $0.110 \mathrm{mg} \cdot l^{-1}, \quad \mathrm{CoCl}_{2} \cdot 6 \mathrm{H}_{2} \mathrm{O} 0.120 \mathrm{mg} \cdot \mathrm{l}^{-1}, \quad \mathrm{Mn}_{2} \mathrm{SO}_{4}$. $\mathrm{H}_{2} \mathrm{O} 0.117 \mathrm{mg} \cdot \mathrm{l}^{-1}, \mathrm{NiCl}_{2} .6 \mathrm{H}_{2} \mathrm{O} 0.104 \mathrm{mg} \cdot \mathrm{l}^{-1}, \mathrm{Na}_{2} \mathrm{HPO}_{4}$ $0.570 \mathrm{mg} \cdot \mathrm{l}^{-1}$, and $\mathrm{FeCl}_{3} \cdot 6 \mathrm{H}_{2} \mathrm{O} 0.124 \mathrm{mg} \cdot \mathrm{l}^{-1}$. The effects of HRT (12 h, $24 \mathrm{~h}$, and $48 \mathrm{~h})$, influent COD concentrations (500 mg $\cdot 1^{-1}, 1000 \mathrm{mg} \cdot \mathrm{l}^{-1}$, and $2000 \mathrm{mg} \cdot \mathrm{l}^{-1}$ ) and electrode spacings $(18 \mathrm{~cm}$ and $28 \mathrm{~cm})$ on wastewater treatment and power generation performance were investigated in CW-MFCs.

\section{Measurement and Calculations}

The influent and effluent samples of reactors were sampled 3-5 days after changing the operating conditions, and were detected every 2 days. COD, $\mathrm{NH}_{4}^{+}-\mathrm{N}$, nitrite, and nitrate were analyzed according to the standard method [32]. The output voltage $\mathrm{U}(\mathrm{mV})$ of both reactors was recorded by a digital multimeter (UNI-T, UT61E) for every $10 \mathrm{~min}$. The volumetric power density $\mathrm{P}\left(\mathrm{mW} \cdot \mathrm{m}^{-3}\right)$ was calculated based on Eq. (1):

$$
P=\frac{U I}{V_{\text {ano }}}=\frac{U^{2}}{R_{e X} V_{\text {ano }}}
$$

...where, $P$ represents the power density, $U$ represents the output voltage, $V_{\text {ano }}$ represents the effective volume of the anode chamber $\left(1.25 \mathrm{~L}\right.$ in this study), and $R_{e x}$ represents the external resistance. In addition, there were a maximum output voltage and a maximum power density which were described as $U_{m}$ and $P_{m}$ in every stage.

\section{Microbial Community Analysis}

At the end of stage 2, the microbial community of the biofilm on anode electrodes was analyzed. Total DNA was extracted by the E.Z.N.A.® soil kit (Omega Biotek, Norcross, GA, USA). DNA concentration and purity were valued by NanoDrop2000. DNA extraction quality was determined by $1 \%$ agarose gel electrophoresis. The PCR-amplified of bacterial 16S rRNA genes used the primers of 338F (5'-ACTCCTACGGGAGGCAGCAG-3') and 806R (5'-GGACTACHVGG- GTWTCTAAT-3'), which target the hypervariable $\mathrm{V}_{3}-\mathrm{V}_{4}$ region. PCR was performed according to established methods [33]. Two samples were sequenced with Illumina Miseq System by Shanghai Majorbio Biopharm Biotechnology Co., Ltd. (Shanghai, China). The raw reads of this study has been deposited in NCBI GenBank with the accession numbers SRR11928279 and SRR11928278.

\section{Results}

Effect of the Hydraulic Retention Time on the Performance of the CW-MFCs

In reactor $\mathrm{A}$, the influence of HRT on COD and $\mathrm{NH}_{4}^{+} \mathrm{N}$ removal efficiencies and biogeneration performance is shown in Table 2 . The result shows that the extension of HRT was beneficial for the removal of $\mathrm{COD}$ and $\mathrm{NH}_{4}{ }^{+}-\mathrm{N}$. And the removal rates of COD and $\mathrm{NH}_{4}^{+}-\mathrm{N}$ reached at their maximum of $91.2 \%$ and $94.1 \%$ respectively when HRT was $48 \mathrm{~h}$. As shown in table 2, the average output voltage increased from 244 to 319 and $324 \mathrm{mV}$ when HRT extended from 12 to 24 and $48 \mathrm{~h}$. The change of power density was similar to that of output voltage. The maximum output voltage $\left(\mathrm{U}_{\mathrm{m}}\right.$, $357 \mathrm{mV})$ and maximum power density $\left(\mathrm{P}_{\mathrm{m}}, 51 \mathrm{~mW} \cdot \mathrm{m}^{-3}\right)$ were reached when the HRT was $24 \mathrm{~h}$, and there was a slight decrease of $\mathrm{U}_{\mathrm{m}}$ and $\mathrm{P}_{\mathrm{m}}$ when HRT changed from $24 \mathrm{~h}$ to $48 \mathrm{~h}$. As can be seen from Table 2, the trend of reactor B was roughly similar to that of reactor A. The above results were consistent with previous reports on MFC: as the HRT increases (4.1 to $16 \mathrm{~h}$ ), the power generation of MFC increases and then decreases, with $\mathrm{P}_{\mathrm{m}}$ obtained at an HRT of $11.3 \mathrm{~h}$, at $22 \mathrm{~W} \cdot \mathrm{m}^{-3}$ [34]. 
Table 2. Effect of HRT on $\mathrm{COD}$ and $\mathrm{NH}_{4}^{+}-\mathrm{N}$ removal and power generation of reactors A and $\mathrm{B}$.

\begin{tabular}{|c|c|c|c|c|c|c|}
\hline \multirow{2}{*}{ Stage } & \multicolumn{2}{|c|}{$1-1$} & \multicolumn{2}{|c|}{$1-2$} & \multicolumn{2}{|c|}{$1-3$} \\
\hline & A & B & A & B & A & B \\
\hline HRT(h) & \multicolumn{2}{|c|}{12} & \multicolumn{2}{|c|}{24} & \multicolumn{2}{|c|}{48} \\
\hline $\mathrm{COD}_{\text {inf }}\left(\mathrm{mg} \cdot \mathrm{l}^{-1}\right)$ & \multicolumn{2}{|c|}{$518 \pm 7$} & \multicolumn{2}{|c|}{$515 \pm 5$} & \multicolumn{2}{|c|}{$518 \pm 6$} \\
\hline $\mathrm{NH}_{4}^{+}-\mathrm{N}_{\text {inf }}\left(\mathrm{mg} \cdot \mathrm{l}^{-1}\right)$ & \multicolumn{2}{|c|}{$24.76 \pm 0.64$} & \multicolumn{2}{|c|}{$24.46 \pm 0.30$} & \multicolumn{2}{|c|}{$24.97 \pm 0.23$} \\
\hline$\Delta \operatorname{COD}\left(\mathrm{mg} \cdot \mathrm{l}^{-1}\right)$ & $387 \pm 9$ & $379 \pm 6$ & $443 \pm 8$ & $423 \pm 1$ & $473 \pm 14$ & $472 \pm 5$ \\
\hline$\Delta \mathbf{N H}_{4}^{+}-\mathrm{N}\left(\mathrm{mg} \cdot \cdot^{-1}\right)$ & $16.28 \pm 1.23$ & $17.68 \pm 0.94$ & $20.83 \pm 0.38$ & $19.99 \pm 0.22$ & $23.41 \pm 0.35$ & $23.61 \pm 0.33$ \\
\hline Average output voltage (mV) & 244 & 167 & 319 & 230 & 324 & 284 \\
\hline $\mathrm{U}_{\mathrm{m}}(\mathrm{mV})$ & 275 & 223 & 357 & 271 & 344 & 307 \\
\hline $\mathrm{P}_{\mathrm{m}}\left(\mathrm{mW} \cdot \mathrm{m}^{-3}\right)$ & 30 & 20 & 51 & 30 & 50 & 38 \\
\hline
\end{tabular}

Note: $\Delta \mathrm{NH}_{4}^{+}-\mathrm{N}=\mathrm{NH}_{4}^{+}-\mathrm{N}_{\text {influent }}-\mathrm{NH}_{4}^{+}-\mathrm{N}_{\text {effluent }}, \Delta \mathrm{COD}=\mathrm{COD}{ }_{\text {influent }}-\mathrm{COD}$ effluent

\section{Effect of Influent COD on the Performance of CW-MFC}

According to the results of the stage 1, the HRT was set to $24 \mathrm{~h}$. In reactor $\mathrm{A}$, the removal rates of $\mathrm{COD}$ and $\mathrm{NH}_{4}^{+}-\mathrm{N}$ and the bioelectricity generation performance under different influent COD are shown in Table 3. Obvious increase of the average net value of COD removal was detected when the influent COD doubled from 500 to $1000 \mathrm{mg} \cdot \mathrm{l}^{-1}$, the removal rate slightly decreased from $86.6 \%$ to $84.5 \%$. The net value of $\mathrm{NH}_{4}^{+}-\mathrm{N}$ removal first increased and then decreased when influent COD increased. When influent COD was changed from 500 to $1000 \mathrm{mg} \cdot \mathrm{l}^{-1}$, influent $\mathrm{NH}_{4}^{+}-\mathrm{N}$ increased from 24.72 to $38.64 \mathrm{mg} \cdot 1^{-1}, \mathrm{NH}_{4}^{+}-\mathrm{N}$ removal rate decreased from $84.51 \%$ to $65.99 \%$, but the net $\mathrm{NH}_{4}^{+}$-N removal still increased from 20.89 to $25.50 \mathrm{mg} \cdot \mathrm{l}^{-1}$. However, when influent COD increased from 1000 to $2000 \mathrm{mg} \cdot \mathrm{l}^{-1}$, influent $\mathrm{NH}_{4}^{+} \mathrm{N}$ was $38.21 \mathrm{mg} \cdot \mathrm{l}^{-1}, \mathrm{NH}_{4}^{+}-\mathrm{N}$ removal rate decreased from $66.0 \%$ to $46.9 \%$. In addition, When the influent COD changed from 500 to $1000 \mathrm{mg} \cdot \mathrm{l}^{-1}$, the average voltage, $\mathrm{U}_{\mathrm{m}}$, and $\mathrm{P}_{\mathrm{m}}$ almost double increased to the maximum, where the average voltage was $524 \mathrm{mV}$, the $\mathrm{U}_{\mathrm{m}}$ was $548 \mathrm{mV}$, and the $\mathrm{P}_{\mathrm{m}}$ was $120 \mathrm{~mW} \cdot \mathrm{m}^{-3}$. However, the output voltage decreased sharply to $33 \mathrm{mV}$ when influent COD changed to $2000 \mathrm{mg} \cdot \mathrm{l}^{-1}$. As can be seen from Table 3, the trend of reactor $\mathrm{B}$ was roughly similar to that of reactor $\mathrm{A}$.

In general, for the biological sewage treatment system, HRT and influent COD could be unified into the organic load. However, comparing the results of stage 1-1 and stage 2-2, it could be seen that the wastewater treatment and power generation performance of the system with HRT of $24 \mathrm{~h}$ was significantly better than that of the system under HRT of $12 \mathrm{~h}$ under the same organic load. This indicates that the organic load cannot be simply used as a single indicator to reflect the effect of organic load on pollutant removal efficiency and power generation performance of the system.

\section{Effect of Electrode Spacing on the Performance of the CW-MFCs}

As shown in Fig. 2, the contaminant removal efficiency of reactor A was slightly better than that of

Table 3. Effect of influent COD on COD and $\mathrm{NH}_{4}{ }^{+}-\mathrm{N}$ removal and power generation of reactors $\mathrm{A}$ and $\mathrm{B}$.

\begin{tabular}{|c|c|c|c|c|c|c|}
\hline \multirow{2}{*}{ Stage } & \multicolumn{2}{|c|}{$2-1$} & \multicolumn{2}{|c|}{$2-2$} & \multicolumn{2}{|c|}{$2-3$} \\
\hline & A & B & A & $\mathrm{B}$ & A & B \\
\hline $\mathrm{COD}_{\text {inf }}\left(\mathrm{mg} \cdot \mathrm{l}^{-1}\right)$ & \multicolumn{2}{|c|}{$515 \pm 5$} & \multicolumn{2}{|c|}{$1008 \pm 10$} & \multicolumn{2}{|c|}{$2014 \pm 11$} \\
\hline $\mathrm{NH}_{4}^{+}-\mathrm{N}_{\mathrm{inf}}\left(\mathrm{mg} \cdot \cdot^{-1}\right)$ & \multicolumn{2}{|c|}{$24.72 \pm 0.56$} & \multicolumn{2}{|c|}{$38.64 \pm 0.79$} & \multicolumn{2}{|c|}{$38.21 \pm 0.77$} \\
\hline$\Delta \mathrm{COD}\left(\mathrm{mg} \cdot \mathrm{l}^{-1}\right)$ & $446 \pm 10$ & $426 \pm 40$ & $911 \pm 7$ & $882 \pm 3$ & $1122 \pm 38$ & $1106 \pm 35$ \\
\hline$\Delta \mathrm{NH}_{4}^{+}-\mathrm{N}\left(\mathrm{mg} \cdot \mathrm{l}^{-1}\right)$ & $20.89 \pm 0.49$ & $20.38 \pm 0.36$ & $25.50 \pm 1.86$ & $25.57 \pm 3.00$ & $17.92 \pm 2.05$ & $15.99 \pm 2.98$ \\
\hline Average output voltage (mV) & 325 & 284 & 524 & 497 & 33 & 31 \\
\hline $\mathrm{U}_{\mathrm{m}}(\mathrm{mV})$ & 348 & 326 & 548 & 540 & 128 & 88 \\
\hline $\mathrm{P}_{\mathrm{m}}\left(\mathrm{mW} \cdot \mathrm{m}^{-3}\right)$ & 48 & 43 & 120 & 117 & 7 & 3 \\
\hline
\end{tabular}

Note: $\Delta \mathrm{NH}_{4}^{+}-\mathrm{N}=\mathrm{NH}_{4}^{+}-\mathrm{N}_{\text {influent }}-\mathrm{NH}_{4}^{+}-\mathrm{N}_{\text {effluent }}, \Delta \mathrm{COD}=\mathrm{COD}_{\text {influent }}-\mathrm{COD}{ }_{\text {effluent }}$ 

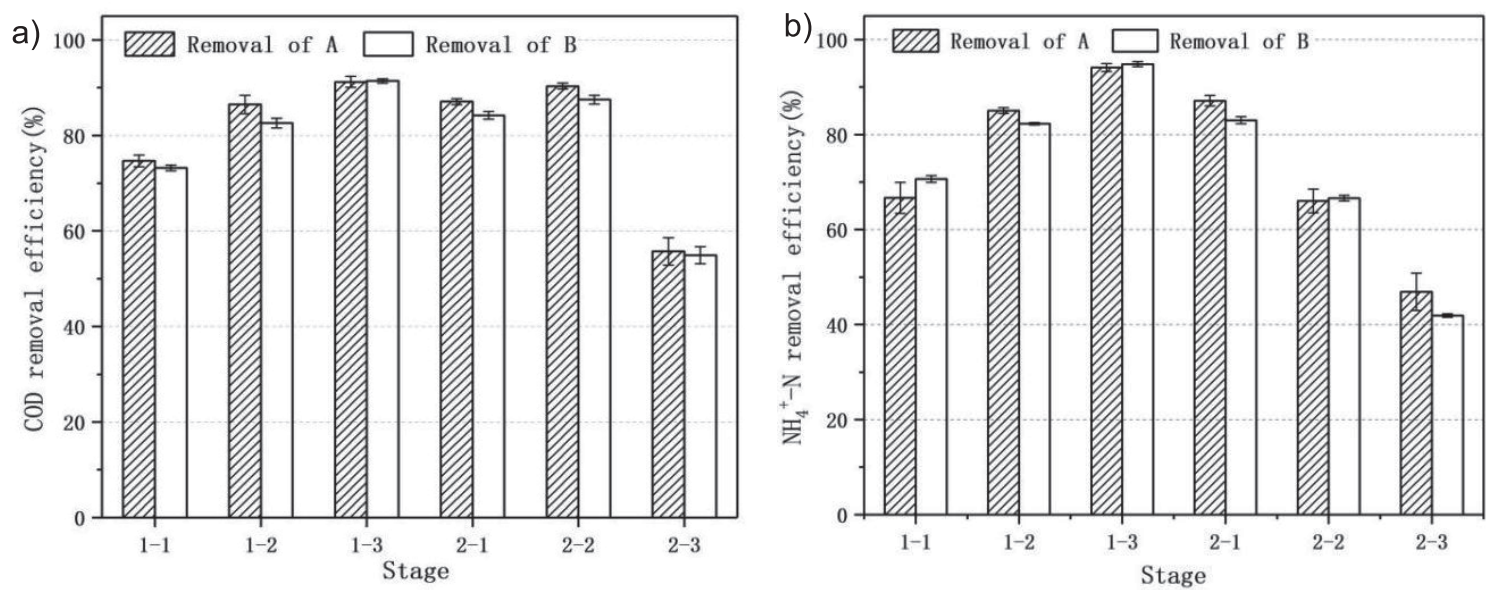

Fig. 2. $\mathrm{COD}$ a) and $\mathrm{NH}_{4}^{+}-\mathrm{N}$ b) removal rates in reactors $\mathrm{A}$ and $\mathrm{B}$ at each stage.

Error bars represent standard deviations.

reactor $\mathrm{B}$. In stage 1 , the average $\mathrm{COD}$ and $\mathrm{NH}_{4}^{+}-\mathrm{N}$ removal rates of reactor $\mathrm{A}$ were $0.2 \sim 4.9 \%$ and $-0.9 \sim 13.7 \%$ higher than those of reactor $\mathrm{B}$, respectively. During stage 2, average COD and $\mathrm{NH}_{4}^{+}-\mathrm{N}$ removal rates of reactor A were $1.5 \sim 4.6 \%$ and $-0.9 \sim 11.9 \%$ higher than those of reactor B, respectively. However, the electrode spacing has a marked impact on electricity generation. As shown in Fig. 3, the average output voltages of reactor $\mathrm{A}$ in stages $2-1,2-2$, and $2-3$ were $14.5 \%, 5.5 \%$, and $9.3 \%$ higher than those of reactor $\mathrm{B}$, respectively. The results show that reactor A performed better than reactor $\mathrm{B}$.

\section{Microbial Community Assessment on the Anode}

The microorganism distribution at the genus level in the biological film is shown on Fig. 4. The dominant genera observed in reactor A include Thauera (4.2\%), Sulfuritalea (3.2\%), Aquaspirillum (3.2\%), Arcobacter (2.9\%), Bacteroidetes_vadinHA17 (2.6\%), Desulfomicrobium (2.4\%), Pseudomonas (2.1\%), Acidaminobacter $(1.9 \%)$, and Geobacter (1.5\%). The dominant genera observed in reactor B include, Geobacter (11.0\%), Bacteroidetes_vadi- nHA17 (4.6\%), Anaerofustis (4.5\%), Sedimentibacter (4.1\%), Arcobacter (3.7\%), Acidaminobacter (2.5\%), Desulfitobacterium (2.2\%), and Macellibacteroides (2.1\%).

\section{Discussion}

This study presents the impact of factors on the wastewater treatment and power generation performance of the CW-MFCs. Result showed that the extension of HRT was beneficial for the contaminants removal and the power generation of the CW-MFCs under high influent load. This may benefit from that the electrogenic bacteria had sufficient time to degrade organic matter and generate power with the extension of HRT. However, excessive extension of
HRT was ineffective for the electricity output. A similar phenomenon was observed in MFCs, where the COD removal rate increased from $32.8 \%$ to $64.8 \%$ as HRT extended from 2.2 to $8.8 \mathrm{~h}$ [35]. The removal rate of COD only increased by $4.7 \%$, and that of $\mathrm{NH}_{4}^{+}-\mathrm{N}$ only increased by $9.0 \%$ when HRT was changed from 24 to $48 \mathrm{~h}$. In addition, there was a slight decrease of $\mathrm{U}_{\mathrm{m}}$ and $\mathrm{P}_{\mathrm{m}}$. This showed that the increase of bioelectricity generation was very limited when HRT was changed from 24 to $48 \mathrm{~h}$. This due to that sufficient organic substrate was vital for metabolism and power generation of microorganisms in the CW-MFCs [36]. The dramatically prolonging HRT led to the failure of the microorganism obtaining sufficient "fuel" for power output. And it also led to the increase of internal mass transfer resistance [37], which was detrimental for electricity generation of MFCs [38]. In conclusion, increasing HRT within a proper range aided power

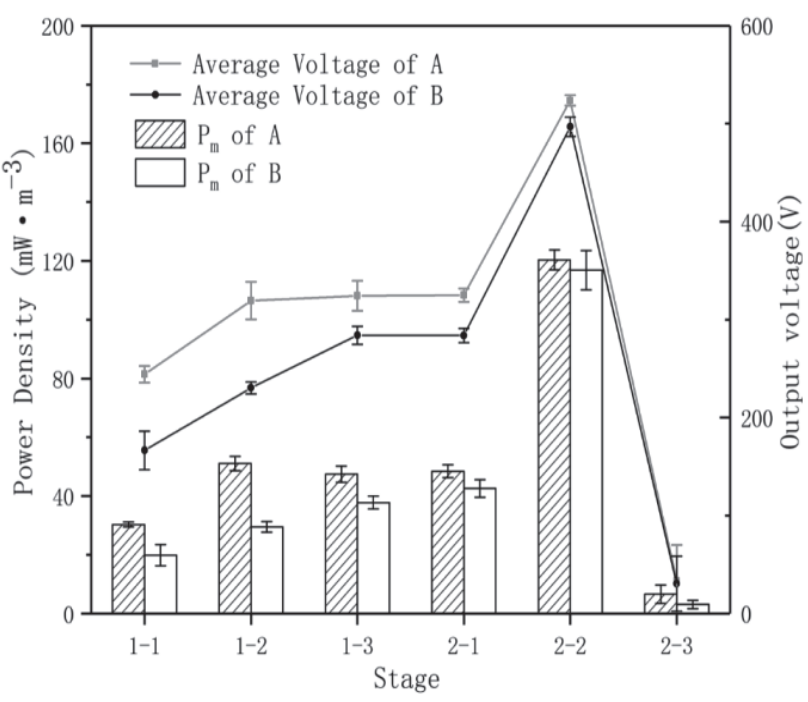

Fig. 3. Bioelectricity generation performances of reactors A and $\mathrm{B}$ at each stage. Error bars represent standard deviations. 


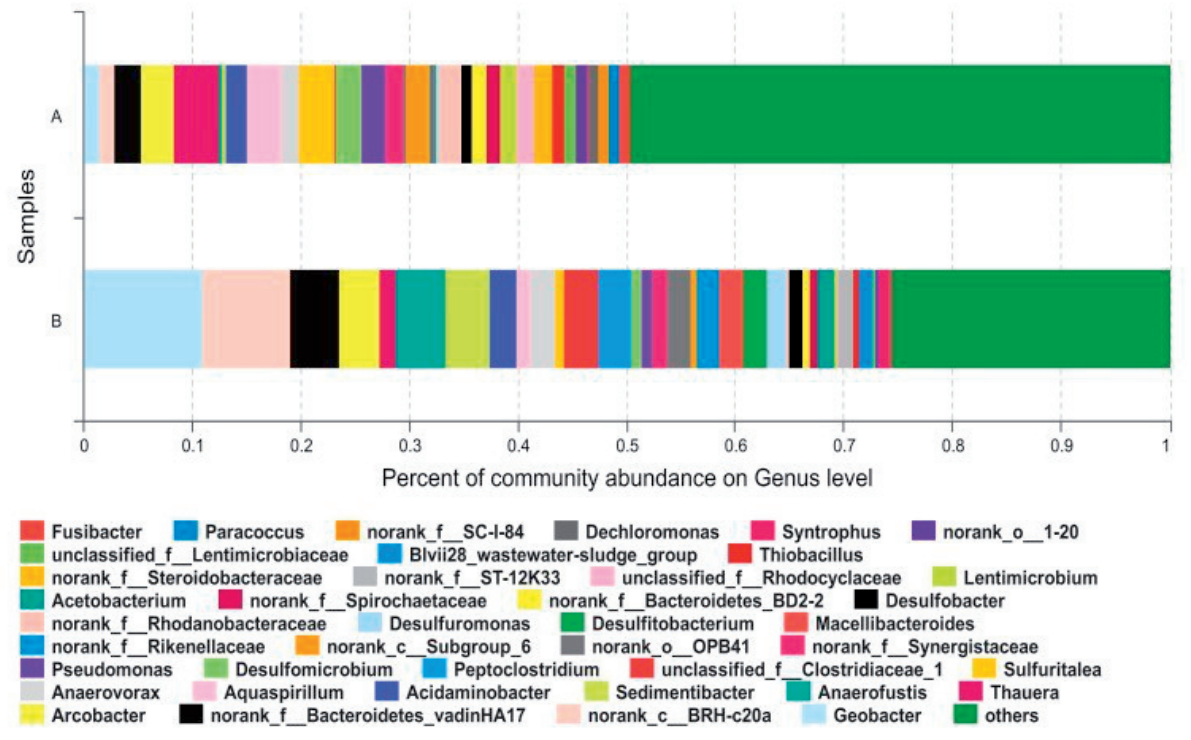

Fig. 4. Bacterial community composition at the genus level in anode samples.

generation, but excessive extension was ineffective. Thus, in consideration of practical engineering application, the optimal HRT was $24 \mathrm{~h}$.

In stage 2, the average net value of COD removal of the reactor increased when influent COD changed from $500 \mathrm{mg} \cdot 1^{-1}$ to $1000 \mathrm{mg} \cdot \mathrm{l}^{-1}$. This may benefit from the facilitation of increased influent COD on the growth of microbes in the CW-MFCs [23]. However, when influent COD increased from $1000 \mathrm{mg} \cdot l^{-1}$ to $2000 \mathrm{mg} \cdot \mathrm{l}^{-1}$, the average net value of COD increased slightly. COD removal rate decreased sharply from $84.5 \%$ to $55.8 \%$. This indicated that the redundant organic substrate had not been utilized and degraded effectively. In addition, the net worth of $\mathrm{NH}_{4}^{+}-\mathrm{N}$ removal first increased and then decreased with increasing of influent COD. The increase of net removal value may benefit from the facilitation of increased influent COD on denitrification which could improve the removal of $\mathrm{NH}_{4}^{+}-\mathrm{N}$ in the system [39]. However, the net value of removal in stage 2-3 was lower than that in stages 2-1 and 2-2. Studies have shown that MFC could significantly enhance TN removal efficiency of CWs by about $4.81 \%$ to $15.48 \%$ [26]. This may be explained by that $\mathrm{NO}_{2-}$ and $\mathrm{NO}_{3-}$ could be interchangeably used as cathodic electron acceptors for nitrogen reduction [40]. However, the increased concentration of organic matrix could enhance the competition between heterotrophic bacteria and nitrifying bacteria [41]. This weakened the activity of nitrifying bacteria and decreased the number of electron acceptors, thus reducing the removal of $\mathrm{NH}_{4}^{+}-\mathrm{N}$. Therefore, although the MFC enhanced the $\mathrm{NH}_{4}^{+}-\mathrm{N}$ removal, the increased influent COD restrained the $\mathrm{NH}_{4}^{+}-\mathrm{N}$ removal in the CW-MFCs. Therefore, when HRT was $24 \mathrm{~h}$, the best influent COD concentration of the system was $1000 \mathrm{mg} \cdot \mathrm{l}^{-1}$.

This study also demonstrated that the increase of influent COD within a certain range was beneficial for the power generation in the CW-MFCs, and it would exert a severely negative impact on the electricity output when the influent COD exceeded the threshold. In this experiment, when the HRT was $24 \mathrm{~h}$, the threshold was $1000 \mathrm{mg} \cdot \mathrm{l}^{-1}$. One explanation for this phenomenon was described in a report that the excessive COD intensified the competition between electrogenic bacteria and other fermentation or methanogenic bacteria in the anode area [42]. Excessive substrate provide suitable growth sites for methanogenic bacteria and improves their activity, which decreases the coulomb efficiency of the system and inhibits the system's power generation ability [43]. This phenomenon was also confirmed in this study. Moreover, under high influent COD concentration $\left(>1000 \mathrm{mg} \cdot \mathrm{l}^{-1}\right)$, the increased organic matter, entering the cathode area without sufficient oxidation would inhibit the cathodic reduction by competing for oxygen, could in turn decrease the output power of the CWMFCs [44].

Comparing the contaminant removal efficiencies and the power generation performance of reactors $\mathrm{A}$ and $\mathrm{B}$, it can be known that reactor $\mathrm{A}$ (with small electrode spacing) performed better to reactor $\mathrm{B}$. This demonstrated that the smaller electrode spacing slightly promoted the sewage treatment efficiency of the CW-MFCs. Other studies have found that this phenomenon was caused by that shorter electrode spacing provided better mass transfer, thus improving the removal of organic matter [45]. Moreover, the results also showed that the smaller electrode spacing was more conducive to power generation, which is consistent with previous study [46]. Therefore, reducing the distance between electrodes was beneficial to increase the output voltage of the system.

The relationship between microbial community structure and function and the power generation performance of the CW-MFCs was also discussed in 
this study. Thauera was a facultative anaerobic species with denitrification capacity, which can be widely found in various types of wastewater treatment plants. However, no studies reported an extracellular electron transport ability of Thauera [47]. Other denitrifying bacteria include Sulfuritalea [48-50] and Aquaspirillum. Bacteroidetes_vadinHA17 was a methanogenic bacterium [51]. Anaerofustis was associated with oxidative degradation of organic compounds [52]. The growth of these acid-producing and methanogenic bacteria may be caused by high influent COD, which indicated that influent COD of the reactor should not stay at a high level for a long time. The general electron transfer mechanisms of microorganisms included: the transfer of electrons through the conducting medium generated by the bacteria themselves [53-55], directly to the electrode through membrane-bound redox compounds [56] and the nanowires generated by cells [57, 58]. Geobacter and Pseudomonas are common electricity-producing bacteria, which can transfer electrons, but the large distance between electrodes has hindered the efficiency of electron transfer, which was consistent with the experimental phenomenon of electricity production performance.

In the experiment, the power generation performance of the reactor increased at first and then decreased with the increase of influent COD concentration, and the power generation performance of the system collapsed when the influent COD was $2000 \mathrm{mg} \cdot \mathrm{l}^{-1}$. This was because when the influent COD concentration increased from $500 \mathrm{mg} \cdot \mathrm{l}^{-1}$ to $1000 \mathrm{mg} \cdot \mathrm{l}^{-1}$, the organic matter concentration in the reactor increased, and the utilization rate of organic matter by microorganisms increased, thus generating more electricity. However, when the concentration of influent COD increased from $1000 \mathrm{mg} \cdot \mathrm{l}^{-1}$ to $2000 \mathrm{mg} \cdot \mathrm{l}^{-1}$, the power generation performance decreased significantly.There were two reasons for this phenomenon. On the one hand, the cathode is the place where protons, electrons and electron receptors produce electricity. Oxygen becomes the commonly used electron acceptor of CWMFCs because of its high potential [59]. When the influent COD was too high, the COD which was not completely oxidized by the anode enters the cathode. Thauera and Bacteroidetes_vadinHA17 are facultative anaerobic bacteria, which compete for oxygen in the cathode region, and the electron reaction in the CW-MFCs also needs oxygen as the electron acceptor. This competition affects the semi-reaction of electricity production in the cathode region, thus reducing the power production performance of the system [60]. The change trend of DO value during the operation of the reactor in Table 1 can verify this conjecture. On the other hand, according to the analysis of COD removal rate, when COD increases from $1000 \mathrm{mg} \cdot 1^{-1}$ to $2000 \mathrm{mg} \cdot \mathrm{l}^{-1}$, although the amount of removal is the same, the power production performance was significantly lower than that when COD was $1000 \mathrm{mg} \cdot \mathrm{l}^{-1}$. This indicated that although a large amount of COD was degraded and utilized, the electrons produced were not effectively captured on the anode electrode, thus reducing the power generation performance [61]. In addition, microorganisms in the reactor detected that Bacteroidetes-vadinHA17 and Bacteroidetes-BD2-2 are acid-producing methane-producing bacteria. In the process of metabolism, these bacteria would compete for the substrate of the electroactive microorganism and the protons in the system, which would reduce the electricity-producing performance [62]. Geobacter was a common electrogenic bacterium with electrically conducting "pili" [63, 64], its extracellular direct electron transfer capacity has been discovered $[65,66]$. Pseudomonas is also a common anode electrogenic bacterium which could secrete the mediator of pyocyanin for electron transfer [67]. From the relative abundance of the two genera Geobacter and Pseudomonas, reactor B (11.0\%) was significantly higher than reactor A $(3.6 \%)$. However, the majority of the bacteria in the anode of the reactor A were gram-negative bacteria, such as Sulfuritalea [49, 68], Aquaspirillum, Arcobacter, Desulfomicrobium [69], Pseudomonas [70], Acidaminobacter [71], Geobacter. Reactor B contained a number of gram-positive bacteria, such as Anaerofustis [66], Sedimentibacter [72], and Desulfitobacterium [73]. Most of the bacteria with electrical activity were gramnegative bacteria [74]. Metabolically, the cell wall of gram-positive bacteria was much thicker than that of negative bacteria because it contains a large amount of peptidoglycan, which hinder electrons conduction. It is generally considered that the electrochemical activity of gram-positive bacteria was less obvious than negative bacteria [74]. Therefore, from the perspective of electron transfer, reactor A with more gram-negative bacteria in the anode microorganisms would has better electroactivity, which was consistent with the phenomenon that the output voltage of reactor A was higher than that of reactor $\mathrm{B}$ as described in sections 3.1 and 3.2 .

\section{Conclusions}

When the HRT was within 12 48 $\mathrm{h}$ and the influent COD was 500 2000 $\mathrm{mg} \cdot \mathrm{l}^{-1}$, this experimental study was carried out. The results showed that when the HRT was $24 \mathrm{~h}$ and the influent COD was $1000 \mathrm{mg} \cdot \mathrm{l}^{-1}$, the maximum power generation performance of the reaction system was obtained. The maximum output voltage was $548 \mathrm{mV}$ and the maximum power density was $120 \mathrm{~mW} \cdot \mathrm{m}^{-3}$. Compared with reactor $\mathrm{B}$, the reduction of electrode spacing helps to improve the power production performance, and the average output voltage was increased by $5.1 \%$ to $46.1 \%$. In the case of optimal HRT and influent COD, the average output voltage of reactor A and B were $524 \mathrm{mV}$ and $497 \mathrm{mV}$ respectively, and the power production performance of reactor A was better than that of reactor B. The total proportion of gram-negative bacteria in reactor $\mathrm{A}$ and 
B anodes was $17.2 \%$ and $14.8 \%$, respectively. From the point of view of electron transfer, it was inferred that reactor A with more Gram-negative bacteria in the anode has better electrical activity, which was consistent with the macroscopic power generation of the reactor.

\section{Acknowledgements}

This work was supported by National Key R\&D Program Specialized "Integrated Technology and Application Demonstration of Rural Water Supply and Drainage in Typical Water-Deficit Areas in the West" (2016YFC0400703-3), the PhD start-up fund of Xi'an university of science and technology (Grant No. 2018QDJ005), Research and Innovation Project Fund of Shaanxi Provincial Education Department (20JK0768), and the open fund of State Key Laboratory of Pollution Control and Resource Reuse (Grant No. PCRRF18014), Xi'an University of Science and Technology Incubation Fund (201724).

\section{Conflict of Interest}

The authors declared no conflict of interest.

\section{References}

1. YING O., CUI L., FENG G., READ J. Simulating phosphorus removal from a vertical-flow constructed wetland grown with C. alternifolius species. Ecological Engineering, 77, 60, 2015.

2. POTTER M.C., SC D., M.A. Electrical effects accompanying the decomposition of organic compounds. Proceedings of the Royal Society of London, 84, 260, 1911.

3. XU L., ZHAO Y., DOHERTY L., HU Y., HAO X. Promoting the bio-cathode formation of a constructed wetland-microbial fuel cell by using powder activated carbon modified alum sludge in anode chamber. Scientific Reports, 6, 26514, 2016.

4. XU F., CAO F.Q., KONG Q., ZHOU L.L., YUAN Q., ZHU Y.J., WANG Q. Electricity production and evolution of microbial community in the constructed wetland-microbial fuel cell. Chemical Engineering Journal, 339, 479, 2018.

5. SRIVASTAVA P., YADAV A.K., MISHRA B.K. The effects of microbial fuel cell integration into constructed wetland on the performance of constructed wetland. Bioresource Technology, 195, 223, 2015.

6. LIU S., SONG H., WEI S. Bio-cathode materials evaluation andconfiguration optimization for power output of vertical subsurfaceflow constructed wetland-Microbial fuel cell systems .BioresourceTechnology, 166 (166c), 575, 2014.

7. OON Y., ONG S., HO L. Hybrid system up-flow constructedwetland integrated with microbial fuel cell for simultaneous wastewater treatment and electricity generation . BioresourceTechnology, 186, 270, 2015.

8. SRIVASTAVA P., YADAV A.K., MISHRA B.K. The effects ofmicrobial fuel cell integration into constructed wetland on theperformance of constructed wetland. Bioresource Technology, 195, 223, 2015.

9. FANG Z, SONG H.L., CANG N. Performance of microbial fuelcell coupled constructed wetland system for decolorization of azo dyeand bioelectricity generation. Bioresource Technology, 144 (6), 165, 2013.

10. Poddar S., Khurana S. Geobacter: the electric microbe! Efficient microbial fuel cells to generate clean, cheap electricity[J]. Indian journal of microbiology, 51 (2), 240, 2011.

11. RABAEY K., BOON N., SICILIANO S.D. Biofuel cells select for microbial consortia that self-mediate electron transfer[J]. Appl. Environ. Microbiol, 70 (9), 5373, 2004.

12. WATANABE T., KOJIMA H., FUKUI M. Complete genomes of freshwater sulfur oxidizers Sulfuricella denitrificans skB26 and Sulfuritalea hydrogenivorans sk43H: genetic insights into the sulfur oxidation pathway of betaproteobacteria [J]. Systematic and applied microbiology, 37 (6), $387,2014$.

13. ZHANG W., LIU X., WANG D. Effects of bamboo charcoal on fouling and microbial diversity in a flat-sheet ceramic membrane bioreactor[J]. Bioresource technology, 243, 1020, 2017.

14. DOHERTY L., ZHAO Y.Q., ZHAO X.H. A review of a recently emerged technology: constructed wetland microbial fuel cells[J]. Water Research, 85, 38, 2015.

15. WANG X., TIAN Y., LIU H., ZHAO X., WU Q. Effects of influent $\mathrm{COD} / \mathrm{TN}$ ratio on nitrogen removal in integrated constructed wetland-microbial fuel cell systems. Bioresource Technology , 271, 492, 2019.

16. RIVERA I., BAKONYI P., BUITRÓN G. H2 production in membraneless bioelectrochemical cells with optimized architecture: The effect of cathode surface area and electrode distance[J]. Chemosphere,1 71, 379, 2017.

17. SHI Y., YANG X., NING X. Research progress of microbial fuel cell and constructed wetland coupling system. Earth and Environmental Science, 199, 1, 2018.

18. GE Z., LI J., XIAO L. Recovery of electrical energy inmicrobial fuel cells: Brief review. Environ Sci Technology, 1, 137, 2014.

19. CLAUWAERT P., VAN DER., HA D., BOON N. Open airbiocathode enables effective electricity generation withmicrobial fuel cells. Environ Sci Technology, 41, 7564, 2007.

20. IEROPOULOS I., et al. Microbial fuel cells based on carbon veil electrodes: Stack configuration and scalability. International Journal of Energy Research, 32 (13), 1228, 2008.

21. YOU J., et al. Novel Analytical Microbial Fuel Cell Design for Rapid in Situ Optimisation of Dilution Rate and Substrate Supply Rate, by Flow, Volume Control and Anode Placement. Energies, 11, 2377, 2018.

22. LI X., ZHU N., YUN W., PING L., WU P., WU J. Animal carcass wastewater treatment and bioelectricity generation in up-flow tubular microbial fuel cells: Effects of HRT and non-precious metallic catalyst. Bioresource Technology, 128, 454, 2013.

23. ADELAJA O., KYAZZE G., KESHAVARZ T. Effect of hydraulic retention time on the performance of a novel tubular MFC fed with petroleum hydrocarbons. New Biotechnology, 31, S98, 2014.

24. KIM K.Y., YANG W., EVANS P.J., LOGAN B.E. Continuous treatment of high strength wastewaters using air-cathode microbial fuel cells. Bioresource Technology, 221, 96, 2016. 
25. SRIKANTH S., KUMAR M., SINGH D., SINGH M.P., DAS B.P. Electro-biocatalytic treatment of petroleum refinery wastewater using microbial fuel cell (MFC) in continuous mode operation. Bioresource Technology, 221, 70, 2016

26. FAZLI N., MUTAMIM N.S.A., JAFRI N.M.A., RAMLI N.A.M. Microbial Fuel Cell (MFC) in Treating Spent Caustic Wastewater: Varies in Hydraulic Retention Time (HRT) and Mixed Liquor Suspended Solid (MLSS). Journal of Environmental Chemical Engineering, 6, 4339, 2018.

27. TANG C., ZHAO Y., KANG C., YANG Y., MORGAN D., XU L. Towards concurrent pollutants removal and high energy harvesting in a pilot-scale CW-MFC: Insight into the cathode conditions and electrodes connection. Chemical Engineering Journal, 373, 150, 2019.

28. CORBELlA C., PUIGAGUT J. Improving domestic wastewater treatment efficiency with constructed wetland microbial fuel cells: Influence of anode material and external resistance. Science of the Total Environment, 631, 1406, 2018.

29. DOHERTY L., ZHAO X., ZHAO Y., WANG W. The effects of electrode spacing and flow direction on the performance of microbial fuel cell-constructed wetland. Ecological Engineering, 79, 8, 2015.

30. SANGEETHA T., MUTHUKUMAR M. Influence of electrode material and electrode distance on bioelectricity production from sago-processing wastewater using microbial fuel cell. Environmental Progress \& Sustainable Energy, 32, 390, 2013.

31. FANG Z., CHENG S., CAO X., WANG H., LI X. Effects of electrode gap and wastewater condition on the performance of microbial fuel cell coupled constructed wetland. Environmental Technology Letters, 38, 1, 2016.

32. EATON A.D., CLESCERI L.S., GREENBERG A.E., FRANSON M.A.H. Standard methods for the examination of water and wastewater. Am J Public Health Nations Health, 56, 387, 1995.

33. YAN X., ZHENG S., HUO Z., SHI B., SUN J. Effects of exogenous $\mathrm{N}$-acyl-homoserine lactones on nutrient removal, sludge properties and microbial community structures during activated sludge process. Chemosphere, 255, 126945, 2020

34. HONG L., CHENG S., HUANG L. Scale-up of membranefree single-chamber microbial fuel cells $[\mathrm{J}]$. Journal of Power Sources, 179 (1), 274, 2008.

35. KIM K.Y., YANG W., LOGAN B.E. Impact of electrode configurations on retention time and domestic wastewater treatment efficiency using microbial fuel cells. Water Research, 80, 41, 2015.

36. SHARMA Y., LI B. Optimizing energy harvest in wastewater treatment by combining anaerobic hydrogen producing biofermentor (HPB) and microbial fuel cell (MFC). International Journal of Hydrogen Energy, 35, 3789, 2010.

37. ZHANG B., ZHANG J., YANG Q., FENG C., ZHU Y., YE Z., NI J. Investigation and optimization of the novel UASB-MFC integrated system for sulfate removal and bioelectricity generation using the response surface methodology (RSM). Bioresource Technology, 124, 1, 2012.

38. LIU R., GAO Y., WANG X., FU J., HAI R., LUO N., LI Y. Effects of hydraulic retention time on MFC coupled A2/O progress for domestic wastewater treatment. Acta Scientiae Circumstantiae, 37, 680, 2017.
39. LIU L., ZHAO X., ZHAO N., SHEN Z., WANG M., GUO Y., XU Y. Effect of aeration modes and influent COD/N ratios on the nitrogen removal performance of vertical flow constructed wetland. Ecological engineering, 57, 10, 2013.

40. LI W., ZHANG S., GANG C., HUA Y. Simultaneous electricity generation and pollutant removal in microbial fuel cell with denitrifying biocathode over nitrite. Applied Energy, 126, 136, 2014.

41. ZHAO J., WU J., LI X., WANG S., HU B., DING X. The Denitrification Characteristics and Microbial Community in the Cathode of an MFC with Aerobic Denitrification at High Temperatures. Frontiers in Microbiology, 8, 1, 2017.

42. MARTIN E., SAVADOGO O., TARTAKOVSKY B. The influence of operational conditions on the performance of a microbial fuel cell seeded with mesophilic sludge. Biochemical Engineering Journal, 51, 132, 2010.

43. JADHAV G.S., GHANGREKAR M.M. Performance of microbial fuel cell subjected to variation in $\mathrm{pH}$, temperature, external load and substrate concentration. Bioresour Technol, 99, 717, 2009.

44. VILLASEÑOR J., CAPILLA P., RODRIGO M.A., CAÑIZARES P., FERNÁNDEZ F.J. Operation of a horizontal subsurface flow constructed wetland-Microbial fuel cell treating wastewater under different organic loading rates. Water Research, 47, 6731, 2013.

45. PARK Y., NGUYEN V.K., PARK S., YU J., LEE T. Effects of anode spacing and flow rate on energy recovery of flat-panel air-cathode microbial fuel cells using domestic wastewater. Bioresour Technol, 258, 57, 2018.

46. OON Y.L., ONG S.A., HO L.N., WONG Y.S., OON Y.S., LEHL H.K., THUNG W.E. Hybrid system up-flow constructed wetland integrated with microbial fuel cell for simultaneous wastewater treatment and electricity generation. Bioresource Technology, 186, 270, 2015.

47. VILAR-SANZ A., PUIG S., GARCÍA-LLEDÓ A., TRIAS R., BALAGUER M.D., COLPRIM J., BAÑERAS L. Denitrifying Bacterial Communities Affect Current Production and Nitrous Oxide Accumulation in a Microbial Fuel Cell. Plos One, 8, e63460, 2013.

48. KOJIMA H., FUKUI M. Sulfuritalea hydrogenivorans gen. nov., sp. nov., a facultative autotroph isolated from a freshwater lake. International Journal of Systematic \& Evolutionary Microbiology, 61, 1651, 2011.

49. WATANABE T., KOJIMA H., FUKUI M. Complete genomes of freshwater sulfur oxidizers Sulfuricella denitrificans skB26 and Sulfuritalea hydrogenivorans sk43H: genetic insights into the sulfur oxidation pathway of betaproteobacteria. Systematic and applied microbiology, 37, 387, 2014.

50. HUANG J.S., GUO Y., YANG P., LI C.M., GAO H., FENG L., ZHANG Y. Performance evaluation and bacteria analysis of AFB-MFC enriched with high-strength synthetic wastewater. Water Science and Technology, 69, 9, 2013.

51. JI Y., LIU P., CONRAD R. Response of fermenting bacterial and methanogenic archaeal communities in paddy soil to progressing rice straw degradation. Soil Biology and Biochemistry, 124, 70, 2018.

52. ZHANG W., LIU X., WANG D., JIN Y. Effects of bamboo charcoal on fouling and microbial diversity in a flat-sheet ceramic membrane bioreactor. Bioresource technology, 243, 1020, 2017.

53. MARSILI E., BARON D.B., SHIKHARE I.D., COURSOLLE D., GRALNICK J.A., BOND D.R. Shewanella secretes flavins that mediate extracellular 
electron transfer. Proceedings of the National Academy of Sciences, 105, 3968, 2008.

54. RABAEY K., BOON N., HÖFTE M., VERSTRAETE W. Microbial phenazine production enhances electron transfer in biofuel cells. Environmental science \& technology, 39, 3401, 2005.

55. ZHANG T., CUI C., CHEN S., YAN H., SHEN P. The direct electrocatalysis of Escherichia coli through electroactivated excretion in microbial fuel cell. Electrochemistry communications, 10, 293, 2008.

56. HOLMES D.E., CHAUDHURI S.K., NEVIN K.P., MEHTA T., METHÉ B.A., LIU A., WARD J.E., WOODARD T.L., WEBSTER J., LOVLEY D.R. Microarray and genetic analysis of electron transfer to electrodes in Geobacter sulfurreducens. Environmental Microbiology, 8, 1805, 2006.

57. GORBY Y.A., YANINA S., MCLEAN J.S., ROSSO K.M., MOYLES D., DOHNALKOVA A., BEVERIDGE T.J., CHANG I.S., KIM B.H., KIM K.S. Electrically conductive bacterial nanowires produced by Shewanella oneidensis strain MR-1 and other microorganisms. Proceedings of the National Academy of Sciences, 103, 11358, 2006.

58. REGUERA G., NEVIN K.P., NICOLL J.S., COVALLA S.F., WOODARD T.L., LOVLEY D.R. Biofilm and nanowire production leads to increased current in Geobacter sulfurreducens fuel cells. Appl Environ Microbiol, 72, 7345, 2006.

59. HEIJNE A.T., LIU F., RIJNSOEVER L.S.V., et al. Performance of a scaled-up Microbial Fuel Cell with iron reduction as the cathode reaction. Journal of Power Sources, 196 (18), 7572, 2011,

60. DU R., CAO S., WANG S., NIU M., PENG Y. Performance of partial denitrification (PD)-ANAMMOX process in simultaneously treating nitrate and low $\mathrm{C} / \mathrm{N}$ domestic wastewater at low temperature. Bioresource technology, 219, 420, 2016.

61. OON Y., ONG S., HO L., et al, Role of macrophyte and effect of supplementary aeration in up-flow constructed wetland-microbial fuel cell for simultaneous wastewater treatment and energy recovery. Bioresource Technology, 224, 265, 2017.

62. ZHANG K.W., LUO X.L., H.B., LI X.K., CHEN W., CHEN J., MO Y., WANG W. $\mathrm{CH}_{4}$ control and associated microbial process from constructed wetland $(\mathrm{CW})$ by microbial fuel cells (MFC). Journal of Environmental Management, 260, 2020.

63. NEVIN K.P., RICHTER H., COVALLA S.F., JOHNSON J.P., LOVLEY D.R. Power output and columbic efficiencies from biofilms of Geobacter sulfurreducens comparable to mixed community microbial fuel cells. Environmental Microbiology, 10, 2505, 2008.

64. PODDAR S., KHURANA S. Geobacter: the electric microbel Efficient microbial fuel cells to generate clean, cheap electricity. Indian journal of microbiology, 51, 240, 2011.

65. SPEERS A.M., REGUERA G. Electron donors supporting growth and electroactivity of Geobacter sulfurreducens anode biofilms. Appl. Environ. Microbiol, 78, 437, 2012.

66. STRYCHARZ-GLAVEN S.M., ROY J., BOYD D., SNIDER R., ERICKSON J.S., TENDER L.M. Electron Transport through Early Exponential Phase Anode Grown Geobacter sulfurreducens Biofilms. Chem Electro Chem, 1, 1957, 2014.

67. RABAEY K., BOON N., SICILIANO S.D., VERHAEGE M., VERSTRAETE W. Biofuel cells select for microbial consortia that self-mediate electron transfer. Appl. Environ. Microbiol, 70, 5373, 2004.

68. KOJIMA H., FUKUI M. Sulfuritalea hydrogenivorans gen. nov., sp. nov., a facultative autotroph isolated from a freshwater lake. International journal of systematic and evolutionary microbiology, 61, 1651, 2011.

69. GENTHNER B., TOWNSEND G.T., BLATTMANN B.O. Reduction of 3-chlorobenzoate, 3-bromobenzoate, and benzoate to corresponding alcohols by Desulfomicrobium escambiense, isolated from a 3-chlorobenzoatedechlorinating coculture. Appl Environ Microbiol, 63, 4698, 1997.

70. LEE S.H., CHOE H., NASIR A., PARK D.S., KIM K.M. Complete genome sequence of nitrilotriacetate-degrading Aminobacter aminovorans KCTC 2477T. Genome Announc, 4, 1316, 2016.

71. FINEGOLD S.M., LAWSON P.A., VAISANEN M.-L., MOLITORIS D.R., SONG Y., LIU C., COLLINS M.D. Anaerofustis stercorihominis gen. nov., sp. nov., from human feces. Anaerobe, 10, 41, 2004.

72. OBST M., KRUG A., LUFTMANN H., STEINBÜCHEL A. Degradation of cyanophycin by Sedimentibacter hongkongensis strain KI and Citrobacter amalonaticus strain $\mathrm{G}$ isolated from an anaerobic bacterial consortium. Appl. Environ. Microbiol, 71, 3642, 2005.

73. MILLIKEN C., MAY H. Sustained generation of electricity by the spore-forming, Gram-positive, Desulfitobacterium hafniense strain DCB2. Applied microbiology and biotechnology, 73, 1180, 2007.

74. LOGAN B.E. Exoelectrogenic bacteria that power microbial fuel cells. Nature Reviews Microbiology, 7, 375, 2009. 